\title{
Leveraging business-IT alignment through enterprise architecture-an empirical study to estimate the extents
}

\author{
Authors \\ Authors and affiliations \\ Morteza AlaeddiniEmail author \\ Hamed Asgari \\ Arash Gharibi \\ Mona Rashidi Rad
}

1.
2.
3.
4.

Article

First Online: 21 March 2016

932Downloads

\section{Citations}

\author{
Abstract \\ Achieving business-IT alignment (BITA) as a long-term and appraising management \\ issue can be accomplished in a few ways, enterprise architecture (EA) being one of them. \\ This paper attempts to give a critical understanding of the effects of performing EA on \\ different aspects of BITA maturity through a global survey. A total of 236 respondents \\ from 60 countries, a relatively large response for a survey, were selected. The main \\ purpose of the research is to examine these impacts and to identify directions for \\ innovative practices in the future, the unique contributions of this work. A questionnaire \\ designed on the Luftman's maturity model as well as various other statistical methods, \\ including PLS path modeling, Wilcoxon matched-pairs signed-ranks test and Mann- \\ Whitney U test, are applied to understand how the EA can deliver benefits. The \\ implications of our findings in this study as well as its limitations are discussed from \\ different viewpoints to enable both academics and practitioners to detect the flaws in the \\ existing EA frameworks and propose improvements.
}




\section{Keywords}

\section{Enterprise architecture (EA) Business-IT alignment (BITA) Luftman's maturity model Partial least squares (PLS)}

This is a preview of subscription content, log in to check access

\section{Notes}

\section{Acknowledgments}

Special thanks are due to Prof. John Zachman for his valuable support and participation in this study. The authors also express their appreciation to Jan van Bon, Manager of LinkedIn group "TOGAF for Architecture," for his time and assistance in the survey. The authors extend their thanks also to Reza Kaviani, Senior Manager at DIRECTV, for his feedback and pertinent help throughout this work. Further, the authors sincerely thank the three anonymous reviewers for their valuable comments.

\section{Appendix 1: Frequencies of BITA maturity scores collected}

Table $\underline{9}$ shows in detail the growth of the BITA maturity levels in this survey in all the measures, after performing EA and comparing them with the values before EA was implemented. This data was collected from 236 respondents around the world for two states: before performing EA and after it was implemented.

\section{References}

\section{1.}

Craig D, Kanakamedala K, Tinaikar R (2007) The next frontier in IT strategy: a

McKinsey Survey. McKinsey Quarterly, SeattleGoogle Scholar

\section{2.}

McGee MK (2008) IT and business alignment remains CIO’s top concern. InformationWeekGoogle Scholar

3.

Reich BH, Benbasat I (2000) Factors that influence the social dimension of alignment between business and information technology objectives. MIS Q 24(1):81113

\section{4.}

Valentine V (2011) IT management concerns changing rapidly. Information ManagementGoogle Scholar

5. 
Alaeddini M, Salekfard S (2013) Investigating the role of an enterprise architecture project in the business-IT alignment in Iran. Inf Syst Front 15(1):67-88CrossRefGoogle $\underline{\text { Scholar }}$

6.

Chen HM (2008) Towards service engineering: service orientation and business-IT alignment. In: 41st Hawaii international conference on system sciences (HICSS), Waikoloa, HI, p 114 Google Scholar

7.

Chen HM, Kazman R, Garg A (2005) BITAM: an engineering-principled method for managing misalignments between business and IT architectures. Sci Comput Program 57(1):5-26CrossRefGoogle Scholar

8.

Gregor S, Hart D (2007) Enterprise architectures: enablers of business strategy and IS/IT alignment in government. Inf Technol People 20(2):96-120 CrossRefGoogle Scholar

9.

Lagerström R, Sommestad T, Buschle M, Ekstedt M (2011) Enterprise architecture management's impact on information technology success. In: 44th Hawaii international conference on system sciences (HICSS), Kauai, HI, pp 1-10 Google Scholar

10.

Ross JW (2003) Creating a strategic IT architecture competency: learning in stages. MIS Q Exec 2(1):31-43Google Scholar

11.

Versteeg G, Bouwman H (2006) Business architecture: a new paradigm to relate business strategy to ICT. Inf Syst Front 8(2):91-102CrossRefGoogle Scholar

12.

Wegmann A, Balabko P, Le LS, Regev G, Rychkova I (2005) A method and tool for business-IT alignment in enterprise architecture. In: The 17th international conference on advanced information systems engineering (CAiSE), Porto, PortugalGoogle Scholar

13.

Wilkinson M (2006) Designing an 'adaptive' enterprise. BT Technol J 24(4):8192CrossRefGoogle Scholar

14.

Bhattacharjya J, Chang V (2006) Evolving IT governance practices for IT and business alignment - a case study in an Australian Institution. In: 4th Annual conference on 
information science, technology and management (CISTM), Chandigarh, IndiaGoogle $\underline{\text { Scholar }}$

\section{5.}

Edwards BA (2000) Chief executive officer behavior: the catalyst for strategic alignment. Int J Value-Based Manag 13(1):47-54다ossRefGoogle Scholar

\section{6.}

Vitantonio GD, Legh-Smith J, Millar W, Wilkinson M (2006) Meeting business objectives through adaptive information and communications technology. BT Technol J 24(4):113-120 CrossRefGoogle Scholar

\section{7.}

Henderson JC, Venkatraman N (1993) Strategic alignment: leveraging information technology for transforming organizations. IBM Syst J 32(1):472-484CrossRefGoogle $\underline{\text { Scholar }}$

\section{8.}

Luftman J, Lewis PR, Oldach SH (1993) Transforming the enterprise: the alignment of business and information technology strategies. IBM Syst J 32(1):198-

221CrossRefGoogle Scholar

\section{9.}

Rathnam RG, Johnsen J, Wen HJ (2005) Alignment of business strategy and IT strategy: a case study of a fortune 50 financial services company. J Comput Inf Syst 45(2):19 $\underline{\text { Google Scholar }}$

20.

Silvius AJG (2008) The impact of national cultures on business \& IT alignment. Commun IIMA 8(2):11-22Google Scholar

\section{1.}

Wegmann A, Regev G, Rychkova I, Lê LS, de la Cruz JD (2007) Business and IT alignment with SEAM for enterprise architecture. In: 11th IEEE international enterprise distributed object computing conference (EDOC), Annapolis, MD, pp 111-121Google $\underline{\text { Scholar }}$

22.

Kang D, Lee J, Kim K (2010) Alignment of business enterprise architectures using factbased ontologies. Expert Syst Appl 37(4):3274-3283CrossRefGoogle Scholar

23. 
van der Raadt B, Bonnet M, Schouten S, van Vliet H (2010) The relation between EA effectiveness and stakeholder satisfaction. J Syst Softw 83(10):1954-

1969CrossRefGoogle Scholar

\section{4.}

Elhari K, Bounabat B (2011) Platform for assessing strategic alignment using enterprise architecture: application to e-government process assessment. Int J Comput Sci Issues 8(1):1-8Google Scholar

25.

Clark T, Barn B, Oussena S (2012) A method for enterprise architecture alignment. In: Proper E, Gaaloul K, Harmsen F, Wrycza S (eds) Practice-driven research on enterprise transformation, vol 120. Lecture notes in business information processing. Springer, Berlin, pp 48-76 Google Scholar

26.

Fritscher B, Pigneur Y (2011) Business IT alignment from Business model to enterprise architecture. In: Advanced information systems engineering workshops. Springer, Berlin, pp 4-15Google Scholar

27.

Luftman J (2000) Assessing business-IT alignment Maturity. Commun Assoc Inf Syst 4(14):1-50Google Scholar

28.

Derzsi Z, Gordijn J (2005) Value-based business-ICT alignment: a case study of the mobile industry. In: 12th research symposium on emerging electronic markets (RSEEM), Amsterdam, Netherlands, pp 83-95Google Scholar

29.

Tapia RS (2007) Developing a maturity model for IT alignment in a cross-organizational environment. In: 2nd Dutch/Belgian conference on enterprise information systems (EIS), Groningen, NetherlandsGoogle Scholar

30.

Shpilberg D, Berez S, Puryear R, Shah S (2007) Avoiding the alignment trap in IT. MIT Sloan Manag Rev 49(1):50-59Google Scholar

31.

Cumps B, Viaene S, Dedene G, Vandenbulck J (2006) An empirical study on business/ICT alignment in European organisations. In: 39th Hawaii international conference on system sciences (HICSS), HI, p 195aGoogle Scholar

32. 
Camponovo G, Pigneur Y (2004) Information systems alignment in uncertain environments. In: IFIP international conference on decision support systems (DSS), Prato, Italy, pp 134-146Google Scholar

33.

Baïna S, Ansias PY, Petit M, Castiaux A (2008) Strategic business/IT alignment using goal models. In: 3rd international workshop on business/IT alignment and interoperability (BUSITAL), Montpellier, France, pp 31-43Google Scholar

34.

Bleistein SJ, Cox K, Verner J, Phalp KT (2006) B-SCP: a requirements analysis framework for validating strategic alignment of organizational IT based on strategy, context, and process. Inf Softw Technol 48(9):846-868CrossRefGoogle Scholar

35.

Carvalho G, Sousa P (2008) Business and information systems MisAlignment model (BISMAM): an holistic model leveraged on misalignment and medical sciences approaches. In: 3rd international workshop on business/IT alignment and interoperability (BUSITAL), Montpellier, France, pp 104-119 $\underline{\text { Google Scholar }}$

36.

Weiss JW, Anderson D (2004) Aligning technology and business strategy: issues \& frameworks, a field study of 15 companies. In: 37th Hawaii international conference on system sciences (HICSS), Big Island, HI, pp 1-10 Google Scholar

37.

Leonard J, Seddon P (2012) A meta-model of alignment. Commun Assoc Inf Syst 31(1):231-259 Google Scholar

38.

Clarke R (1994) The path of development of strategic information systems theory. http://www.rogerclarke.com/SOS/StratISTh.html

39.

Wegmann A (2002) The systemic enterprise architecture methodology business and IT alignment for competitiveness. In: EPFL, Lausanne, Switzerland, pp 1-8 $\underline{\text { Google Scholar }}$ 40.

Yetton PW, Johnston KD, Craig JF (1994) Computer-aided architects: a case study of it and strategic change. Sloan Manag Rev 35(4):57-67 $\underline{\text { Google Scholar }}$

41. 
van Eck P, Blanken H, Wieringa R (2004) Project GRAAL: towards operational architecture alignment. Int J Coop Inf Syst 13(3):235-255CrossRefGoogle Scholar

42.

Baker J, Jones D, Cao Q, Song J (2011) Conceptualizing the dynamic strategic alignment competency. J Assoc Inf Syst 12(4):299-322Google Scholar

43.

Chang HL, Hsiao HE, Lee YJ, Chang J (2009) Assessing IT-business alignment in service-oriented enterprises. In: PACIS, p 40Google Scholar

44.

Gutierrez A, Orozco J, Serrano A (2006) Using tactical and operational factors to assess strategic alignment: an SME study. In: European and mediterranean conference on information systems (EMCIS), Costa Blanca, Alicante, Spain, pp 1-10 Google Scholar

45.

Papp R (2001) Introduction to strategic alignment. In: Papp R (ed) Strategic information technology: opportunities for competitive advantage. illustrated edn. IGI Glob, Hershey, PA, pp 1-24Google Scholar

46.

Silva E, Plazaola L, Ekstedt M (2006) Strategic business and IT alignment: a prioritized theory diagram. In: PICMET, Istanbul, Turkey, pp 1-10Google Scholar

47.

Tapia RS, Daneva M, van Eck P (2007) Validating adequacy and suitability of businessIT alignment criteria in an inter-enterprise maturity model. In: 11th IEEE international conference on enterprise distributed object computing (EDOC), Annapolis, MD, pp 202213Google Scholar

48.

Wang N, Xue Y, Liang H, Ge S (2011) The road to business-it alignment: a case study of two Chinese companies. Commun Assoc Inf Syst 28(1):416-436Google Scholar

49.

Luftman J, Papp R, Brier T (1999) Enablers and Inhibitors of business-IT alignment. Commun Assoc Inf Syst 11(3):1-33Google Scholar

50.

Luftman J (1996) Competing in the information age: strategic alignment in practice. Oxford University Press, New YorkGoogle Scholar

51. 
Weill P, Ross JW (2004) IT governance-how top performers manage IT decision rights for superior results. Harvard Business School Press, BostonGoogle Scholar

52.

Weill P, Ross JW (2004) IT governance on one page. Massachusetts, CambridgeGoogle $\underline{\text { Scholar }}$

53.

Team CP (2010) CMMI ${ }^{\circledR}$ for development, version 1.3, Improving processes for developing better products and services. no CMU/SEI-2010-TR-033 Software Engineering InstituteGoogle Scholar

54.

Giachetti RE (2010) Design of enterprise systems, theory, architecture, and methods. CRC Press, Boca RatonGoogle Scholar

55.

Jahani B, Seyyed Javadein SR, Jafari HA (2010) Measurement of enterprise architecture readiness within organizations. Business Strategy Series 11(3):177-191rossRefGoogle $\underline{\text { Scholar }}$

56.

Shah H, Kourdi ME (2007) Frameworks for enterprise architecture. IT Prof 9(5):3641Google Scholar

57.

Zachman JA (2002) The Zachman framework ${ }^{\mathrm{TM}}$ for enterprise architecture. Zachman International:79 Google Scholar

58.

CIO-Council (2001) A practical guide to federal enterprise architecture, version 1.0Google Scholar

59.

Spewak S, Hill SC (1995) Enterprise architecture planning: developing a blueprint for data, applications, and technology. Wiley, New York CityGoogle Scholar

60.

ITGI (2007) Control objectives for information and related technology (COBIT), Ver 4.1. IT Governance Institute (www.itgi.org)

61. 
The-Open-Group (2009) The Open group architecture framework (TOGAF), version 9.0Google Scholar

\section{2.}

Pereira CM, Sousa P (2005) Enterprise architecture: business and IT alignment. In: ACM symposium on applied computing, Santa Fe, NM, USA, pp 1344-1345Google Scholar

63.

Veasey PW (2001) Use of enterprise architectures in managing strategic change. Bus Process Manag 7(5):420-436CrossRefGoogle Scholar

64.

Engelsman W, Quartel D, Jonkers H, van Sinderen M (2011) Extending enterprise architecture modelling with business goals and requirements. Enterp Inf Syst 5(1):936CrossRefGoogle Scholar

65.

Xueying W, Feicheng M, Xiongwei Z (2008) Aligning business and IT using enterprise architecture. In: 4th international conference on wireless communications, networking and mobile computing (WiCOM), Dalian, pp 1-5 $\underline{\text { Google Scholar }}$

66.

Tamm T, Seddon PB, Shanks G, Reynolds P (2011) How does enterprise architecture add value to organisations? Commun Assoc Inf Syst 28(1):141-168Google Scholar

67.

Seigerroth U (2011) Enterprise modeling and enterprise architecture: the constituents of transformation and alignment of business and IT. Int J IT/Bus Align Gov (IJITBAG) 2(1):16-34CrossRefGoogle Scholar

68.

Bradley RV, Pratt RME, Byrd TA, Simmons L (2011) The role of enterprise architecture in the quest for it value. MIS Q Exec 10(2):19-27Google Scholar

69.

Bradley RV, Pratt RME, Byrd TA, Outlay CN, Wynn DE Jr (2012) Enterprise architecture, IT effectiveness and the mediating role of IT alignment in US hospitals. Inf Syst J 22(2):97-127CrossRefGoogle Scholar

70.

Saat J, Franke U, Lagerström R, Ekstedt M (2010) Enterprise architecture meta models for IT/business alignment situations. In: 14th IEEE international conference on enterprise distributed object computing (EDOC), Vitoria, Brazil, pp 14-23 
Varghese J, Kurien P (2004) IT imperatives beyond strategic alignment: enterprise architecture flexibility and IT delivery efficiency. Handb Bus Strategy 5(1):275279CrossRefGoogle Scholar

\section{2.}

Plazaola L, Flores J, Vargas N, Ekstedt M (2008) Strategic business and IT alignment assessment: a case study applying an enterprise architecture-based metamodel. In: 41st Hawaii international conference on system sciences, Waikoloa, HI, p 398Google Scholar

73.

Wang X, Zhou X, Jiang L (2008) A method of business and IT alignment based on enterprise architecture. In: IEEE international conference on service operations and logistics, and informatics (IEEE/SOLI), Beijing, pp 740-745

\section{4.}

Aier IS, Winter R (2009) Virtual decoupling for IT/business alignment-conceptual foundations, architecture design and implementation example. Bus Inf Syst Eng 1(2):150-163CrossRefGoogle Scholar

75.

Haki MK, Forte MW (2010) Proposal of a service oriented architecture governance model to serve as a practical framework for business-IT alignment. In: 4th International conference on new trends in information science and service science (NISS), Gyeongju, pp 410-417 $\underline{\text { Google Scholar }}$

76.

PMI (2008) A guide to the project management body of knowledge. Project Management Institute, Inc, PA $\underline{\text { Google Scholar }}$

77.

Foorthuis R, van Steenbergen M, Brinkkemper S, Bruls WA (2015) A theory building study of enterprise architecture practices and benefits. Inf Syst Front 1-24.

doi: $10.1007 / \mathrm{s} 10796-014-9542-1$

78.

Bahrami A, Sadowski D, Beahrami S (1998) Enterprise architecture for business process simulation. In: Winter simulation conference (WSC), Washington, DC, pp 14091413Google Scholar

79. 
Buckl S, Matthes F, Schweda CM (2009) Future research topics in enterprise architecture management - a knowledge management perspective. In: International conference on service-oriented computing (ICSOC), Stockholm, Sweden, pp 1-11Google Scholar

80.

El Kourdi M, Shah H, Atkins A (2007) A proposed framework for knowledge discovery in enterprise architecture. In: Trends in enterprise architecture research (TEAR), St. Gallen, Switzerland, pp 41-49 Google Scholar

81.

Jafari M, Akhavan P, Nouranipour E (2009) Developing an architecture model for enterprise knowledge: an empirical study based on the Zachman framework in Iran. Manag Decis 47(5):730-759 $\underline{\text { CrossRefGoogle Scholar }}$

82.

Ross J (2006) Enterprise architecture: driving business benefits from IT. 359,

Massachusetts Institute of Technology. Center for Information Systems Research (CISR), Cambridge, MA $\underline{\text { Google Scholar }}$

83.

Vail E (2002) Knowledge management \& enterprise architecture: an opportunity for synergy. White paper. Ptech Inc., Quincy, MassachusettsGoogle Scholar

84.

Cotton LD, Haase GA, Havlicek JD, Thal AE (2009) Value driven enterprise architecture score (VDEAScore): A means of DoDAF architecture evaluation. In: 7th Annual conference on systems engineering research (CSER), Leicestershire, UKGoogle Scholar

85.

Gustafsson P, Johnson P, Nordstrom L (2009) Enterprise architecture: A framework supporting organizational performance analysis. In: 20th International conference and exhibition on electricity distribution, Prague, Czech Republic, pp 1-4 $\underline{\text { Google Scholar }}$

86.

Ostadzadeh SS, Habibi J, Ostadzadeh SA (2010) A framework for decision support systems based on Zachman framework. In: Elleithy K (ed) Advanced techniques in computing sciences and software engineering. Springer, Netherlands, pp 497502CrossRefGoogle Scholar

87.

Schelp J, Stutz M (2007) A Balanced Scorecard Approach to Measure the Value of Enterprise Architecture. Journal of Enterprise Architecture 3(4):8-14 $\underline{\text { Google Scholar }}$

88. 
Velitchkov I (2008) Integration of IT strategy and enterprise architecture models. Paper presented at the 9th International Conference on Computer Systems and Technologies and Workshop for PhD Students in Computing, Gabrovo, BulgariaGoogle Scholar

89.

Lindstrom A, Johnson P, Johansson E, Ekstedt M, Simonsson M (2006) A survey on CIO concerns - do enterprise architecture frameworks support them? Inf Syst Front 8(2):8190CrossRefGoogle Scholar

90.

Molinaro LFR, Ramos KHC, Cotta Orlandi TR, Abdalla H (2010) Enterprise architecture to IT governance: an approach based on component business model and performance levels. In: Quintela Varajão JE, Cruz-Cunha MM, Putnik GD, Trigo A (eds) Enterprise information systems, vol 110. Communications in computer and information science. Springer, Berlin, pp 41-51Google Scholar

91.

Nakakawa A, van Bommel P, Proper E (2010) Towards a theory on collaborative decision making in enterprise architecture. In: Winter R, Zhao J, Aier S (eds) Global perspectives on design science research, vol 6105. Lecture notes in computer science. Springer, Heidelberg, pp 538-541Google Scholar

92.

Ireland V (2007) Enterprise architecture-a layer between portfolios and organisation strategy. In: 4th World project management week conference, SingaporeGoogle Scholar

93.

Ross J, Weill P, Robertson DC (2006) Enterprise architecture as strategy: create a foundation for business execution. Harvard Business School Press, BostonGoogle Scholar

94.

Fairhead N, Good J (2009) People-led enterprise architecture. In: Saha P (ed) Advances in government enterprise architecture. IGI Global, Pennsylvania, pp 285306CrossRefGoogle Scholar

95.

Coltman T, Devinney TM, Midgley DF, Venaik S (2008) Formative versus reflective measurement models: two applications of formative measurement. J Bus Res 61(12):1250-1262CrossRefGoogle Scholar

96.

Diamantopoulos A, Siguaw JA (2006) Formative versus reflective indicators in organizational measure development: a comparison and empirical illustration. Br J Manag 17(4):263-282CrossRef 
97.

Jarvis CB, MacKenzie SB, Podsakoff PM (2003) A critical review of construct indicators and measurement model misspecification in marketing and consumer research. J Consum Res 30(2):199-218CrossRefGoogle Scholar

98.

Sharp H, Rogers Y, Preece J (2002) Interaction design: beyond human-computer interaction. Wiley, HobokenGoogle Scholar

99.

Presser S, Rothgeb JM, Couper MP, Lessler JT, Martin E, Martin J, Singer E (2004) Methods for testing and evaluating survey questionnaires. Wiley, HobokenCrossRefGoogle Scholar

100.

Groves RM, Fowler FJ, Couper MP, Lepkowski JM, Singer E, Tourangeau R (2009) Survey methodology, 2nd edn. Wiley, HobokenGoogle Scholar

101.

Bradburn NM, Sudman S, Wansink B (2004) Asking questions: the definitive guide to questionnaire design — for market research, political polls, and social and health questionnaires. WileyGoogle Scholar

102.

Couper MP, Baker RP, Bethlehem J, Clark CZF, Martin J, Nicholls WL, O’Reilly JM (1998) Computer assisted survey information collection. Wiley, HobokenGoogle Scholar

103.

Sandelowski M (1995) Sample size in qualitative research. Res Nurs Health 18(2):179_ 183CrossRefGoogle Scholar

104.

Adcock R, Collier D (2001) Measurement validity: a shared standard for qualitative and quantitative research. Am Polit Sci Rev 95(3):529-546CrossRefGoogle Scholar

105.

Chin WW, Newsted PR (1999) Structural equation modeling analysis with small samples using partial least squares. In: Hoyle RH (ed) Statistical strategies for small sample research. Sage, Thousand OaksGoogle Scholar

106. 
Fornell C (1987) A second generation of multivariate analysis: classification of methods and implications for marketing research. In: Houston MJ (ed) Review of marketing. American Marketing Association, ChicagoGoogle Scholar

107.

Chen L (2010) Business-IT alignment maturity of companies in China. Inf Manag 47(1):9-16CrossRefGoogle Scholar

108.

Sledgianowski D, Luftman J, Reilly RR (2006) Development and validation of an instrument to measure maturity of IT business strategic alignment mechanisms. Inf Resourc Manag J 19(3):18-33 CrossRefGoogle Scholar

109.

Carifio L, Perla R (2008) Resolving the 50-year debate around using and misusing Likert scales. Med Educ 42(12):1150-1152CrossRefGoogle Scholar

110.

Norman G (2010) Likert scales, levels of measurement and the "laws" of statistics. Adv Health Sci Educ 15(5):625-632CrossRefGoogle Scholar

111.

Sheskin DJ (2004) Handbook of parametric and nonparametric statistical procedures, 3rd edn. Chapman \& Hall/CRC, Boca RatonGoogle Scholar

112.

Anastasi A, Urbina S (1997) Psychological testing, 7th edn. Prentice-Hall, Upper Saddle RiverGoogle Scholar

113.

DeVon HA, Block ME, Moyle-Wright P, Ernst DM (2007) A psychometric toolbox for testing validity and reliability. J Nurs Scholarsh 39(2):155-164CrossRefGoogle Scholar

114.

Vaishnavi VK, Kuechler W (2008) Design science research methods and patternsinnovating information and communication technology. Auerbach Publications, NYGoogle Scholar

115.

Chin WW (1995) Partial least squares is to LISREL as principal components analysis is to common factor analysis. Technol Stud 2(2):315-319 Google Scholar

116. 
Rossiter JR (2002) The C-OAR-SE procedure for scale development in marketing. Int J Res Mark 19(4):305-335CrossRefGoogle Scholar

\section{7.}

Petter S, Straub D, Rai A (2007) Specifying formative constructs in information systems research. MIS Q 31(4):623-656Google Scholar

\section{8.}

Roberts N, Thatcher J (2009) Conceptualizing and testing formative constructs: tutorial and annotated example. ACM SIGMIS Database 40(3):9-39 CrossRefGoogle Scholar

\section{9.}

Henseler J, Ringle CM, Sinkovics RR (2009) The use of partial least squares path modeling in international marketing. Adv Int Mark (AIM) 20(1):277-320Google Scholar

120.

Straub D, Boudreau M-C, Gefen D (2004) Validation guidelines for IS positivist research. Commun Assoc Inf Syst 13(1):63Google Scholar

121.

Cohen J (1988) Statistical power analysis for the behavioral sciences. Lawrence Erlbaum Associates, HillsdaleGoogle Scholar

122.

Hair JF Jr, Hult GTM, Ringle C, Sarstedt M (2013) A primer on partial least squares structural equation modeling (PLS-SEM). Sage Publications, Thousand OaksGoogle $\underline{\text { Scholar }}$

123.

Hair JF, Anderson RE, Tatham RL, Black WC (1998) Multivariate data analysis, 5th edn. Prentice Hall, Upper Saddle RiverGoogle Scholar

124.

Woszczynski AB, Whitman ME (2004) The problem of common method variance in IS research. In: Whitman ME, Woszczynski AB (eds) The handbook of information systems research. IGI Glob, Hershey, PA, pp 66-77 Google Scholar

125.

Lindell MK, Whitney DJ (2001) Accounting for common method variance in crosssectional research designs. J Appl Psychol 86(1):114CrossRefGoogle Scholar 
Tenenhaus M, Esposito Vinzi V, Chatelin YM, Lauro C (2005) PLS path modeling. Comput Stat Data Anal 48(1):159-205CrossRefGoogle Scholar

127.

Esposito Vinzi V, Trinchera L, Amato S (2010) PLS path modeling: from foundations to recent developments and open issues for model assessment and improvement. In: Esposito Vinzi V, Chin WW, Henseler J, Wang H (eds) Handbook of partial least squares, vol 47-82. Springer, BerlinCrossRefGoogle Scholar

128.

Brown TA (2006) Confirmatory factor analysis for applied research. Methodology in the social sciences. Guilford Publications Inc, New YorkGoogle Scholar

129.

Hair JF, Ringle CM, Sarstedt M (2011) PLS-SEM: indeed a silver bullet. J Mark Theory Pract 9(2):139-151CrossRefGoogle Scholar

130.

Wold H (1980) Factors affecting the outcome of economic sanctions: an application of soft modelling. Paper presented at the 4th World Congress of Econometric Society, Aixen-provence, France, 1-3 MayGoogle Scholar

131.

Falk RF, Miller NB (1992) A primer for soft modelling. University of Akron Press, AkronGoogle Scholar

132.

Yeniay O, Göktaş A (2002) A Comparison of partial least squares regression with other prediction methods. Hacet J Math Stat 31(99):99-111 Google Scholar

133.

Howell RD, Breivik E, Wilcox JB (2007) Reconsidering formative measurement. Psychol Methods 12(2):205CrossRefGoogle Scholar

134.

Chin WW, Marcolin BL, Newsted PR (1996) A partial least squares latent variable modeling approach for measuring interaction effects: results from a Monte Carlo simulation study and voice mail emotion/adoption study. In: DeGross JI, Jarvenpaa S, Srinivasan A (eds) 17th International conference on information systems, Cleveland, OhioGoogle Scholar

135. 
Hulland J (1999) Use of partial least squares (PLS) in strategic management research: a review of four recent studies. Strateg Manag J 20(2):195-204CrossRefGoogle Scholar

136.

Urbach N, Ahlemann F (2010) Structural equation modeling in information systems research using partial least squares. J Inf Technol Theory Appl 11(2):5-40Google Scholar

137.

Efron B (1979) Bootstrap methods: another look at the jackknife. Ann Stat 7(1):126CrossRefGoogle Scholar

138.

Efron B, Tibshirani RJ (1994) An introduction to the bootstrap, vol 57. CRC Press, Boca RatonGoogle Scholar

139.

Chin WW (1998) Issues and opinion on structural equation modeling. MIS Q 22(1):59Google Scholar

140.

Henseler J, Sarstedt M (2013) Goodness-of-fit indices for partial least squares path modeling. Comput Stat 28(2):565-580CrossRefGoogle Scholar

141.

Geisser S (1974) A predictive approach to the random effect model. Biometrika 61(1):101-107CrossRefGoogle Scholar

142.

Stone M (1974) Cross-validatory choice and assessment of statistical predictions. J R Stat Soc Ser B (Methodological) 36(2):111-147Google Scholar

143.

Siegel S (1956) The Mann-Whitney U test. Nonparametric statistics for the behavioral sciences. McGraw-Hill, New York, NY, USGoogle Scholar

144.

McKnight PE, Najab J (2010) Mann-Whitney U Test. In: Weiner IB, Craighead WE (eds) Corsini encyclopedia of psychology. Wiley, onlineGoogle Scholar

145.

Moore DA, Tanlu L, Bazerman MH (2010) Conflict of interest and the intrusion of bias. Judgm Decis Mak 5(1):37-53Google Scholar 
146.

Urbaczewski L, Mrdalj S (2006) A comparison of enterprise architecture frameworks. Issues Inf Syst 7(2):18-23Google Scholar

147.

Tang A, Han J, Chen P (2004) A comparative analysis of architecture frameworks. In: 11th Asia-Pacific software engineering conference. IEEE, pp 640-647Google Scholar

148.

Sessions R (2007) Comparison of the top four enterprise architecture methodologies. ObjectWatch Inc.Google Scholar

149.

Snijders CCP, Matzat U (2007) Reducing social desirability bias through indirect questioning in scenarios: When does it work in online surveys? Paper presented at the General Online Reseach, GOR07, Leipzig, March 26-28, 2007Google Scholar 